\title{
On Students' Subjectivity in English Teaching
}

\author{
Yong WANG \\ Linyi University, Feixian Campus, Feixian, Shandong, China \\ Email:lydxmfl@126.com
}

Keywords: Students, Subjectivity, English teaching.

\begin{abstract}
As a language practice course, the achievement of the prescriptive language skills needs students' active participation and repeated practice. Only after they fulfill these can they achieve the standard of proficiency. As English teachers, we should break through the traditional classroom teaching mode, not regard the students as the “containers", but the main parts, promote students' active and full participation in the whole teaching process and maximize the students' autonomy, initiative and creativity.
\end{abstract}

\section{Introduction}

The characteristics of English as a practical subject require students should have certain abilities of listening, speaking, reading and writing. So it is important for students to practice English actively besides learning corresponding knowledge. In English teaching practice, students are the subject parts. The ultimate scale of measuring English teaching efficiency is the degree of students' mastering English. Students' subjectivity, simply speaking, refers to students as the main parts of learning activities and the active development of their own potential. Students should be the center of teaching activities. Teachers, teaching materials and teaching methods act as the service of students' learning. Teachers can only serve as students' guides or facilitators in learning English, guide students to actively participate in teaching activities and play the parts of leading roles in the teaching activities, rather than "teachers as instructors and students as "containers", which only lead to the result of students' passive acceptance of English[1]. We should clearly recognize that things internal contradiction is the source of things development and it determines the nature and direction of the development of things, which is the root cause of the development of things. External cause is the changing conditions and internal cause is the basis of the change, which works through internal causes. In the teaching process, the root cause of students development of knowledge, ability, quality and character lies in their internal contradictions. Teachers' level, teaching content, teaching methods and teaching equipment are all external causes for students, which work through internal causes. Teachers cannot replace students to engage in learning activities. Therefore, it is an important question to discuss how to mobilize students' learning initiative and establish their own subjectivity consciousness.

First of all, teachers should have the correct educational concepts; the manifestation 
of promoting students' main parts position requires bringing their initiative and enthusiasm into full play and establishing their main parts status. So teachers should do the following things if they want to improve their teaching efficiency.

\section{Create Democratic, Equal and Harmonious Classroom Atmosphere.}

The manifestation of students' main part status requires democratic, equal and harmonious classroom atmosphere, which is helpful for communication and understanding between students and teachers. Only in the environment of democracy and equality can students show their awareness of subjectivity. The relationship between teachers and students in the concept of subjective education should be a kind of objective inequality while subjective equality and democracy [2]. The objective inequality refers to teachers and students are not equal in the aspect of knowledge. But subjectively, teachers should regard students as the equal social members with themselves, respect them, care for them, and realize the harmonious unification of emotion. The classroom should become a harmonious educational place where students' subjectivity awareness would be strengthened and their learning potential would be developed and therefore their study efficiency would be improved [3].

\section{Employ the Method of the Combination of Students-oriented Teaching with Hierarchic Teaching.}

Students-oriented is the common trend of the current world education reform. Each student has its own unique personality. The differences in their intelligence, original knowledge level and cognitive style resulted in their different levels in English learning. Therefore, in order to make English teaching adapt to students' different study status and let each student get full development, we must adhere to the principle of teaching students in accordance with their aptitude, that is, English level-based teaching according to students' original English knowledge level, cognitive ability and personality characteristics. The implementation of hierarchical teaching can give each student necessary time and space of independent performance and development and prompt the all-round development of different students.

Hierarchic-teaching includes hierarchical students, hierarchical teaching purposes, hierarchical classroom teaching, hierarchical practice and hierarchical evaluation etc. Teachers take the appropriate strategies in the process of English teaching according to students' different levels to support and encourage students to bring their subjectivity into full play and feel the joy of success and pride in the process of English learning, so as to promote English teaching and furthermore advance students' development in English learning.

\section{Give Students Enough Learning Time and Space in Englis h Teaching Activities.}

Students' free expression in the teaching activities is their subject participation in the English classroom. There would be no subject participation in English teaching without the free students. Students participate in the teaching activities in the identity of learners. They are the participants and practitioners of English subject practice 
activities and English knowledge cognition activities. They are the main parts of English learning. The roles of the teachers are the organizers and leaders of English teaching activities, which require the construction of a new type of classroom teaching structure, so that students can fully express themselves in the classroom. Teachers should highlight the combination of intensive teaching and brief practice in order to give students enough time and space in the classroom to take part in the English learning. Knowledge shouldn't be taught as the result of thinking. The subjectivity of students should be played fully and they should take part in the process of English learning as the subjects of thinking. In the classroom students can read new words and text after the leading reading of one of them, correct their homework by themselves and let some students ask questions while others answer these questions, which enable students to participate fully in the teaching activities. At the same time, teachers should converse the teaching contents into life practice as much as possible. So that classroom teaching could become a place where students could communicate with English, practice their abilities of listening, speaking, reading and writing and further develop their intelligence.

\section{Help Students Get Hold of Methods of English Learning}

In order to establish students' subjectivity consciousness, students' learning methods should be made to conform to the cognitive rules of English subject. Exploring of teaching methods on the basis of studying learning methods could make them learn English in accordance with the cognitive rules of English subject. The significance of English teaching is to teach the methods of learning, that is, let the students know how to self-study English, and then be good at learning English. In the classroom teaching, knowledge has double attribute, that is, it is not only the knowledge itself, but also the material of training thought. The aim of English teaching is to help students get hold of learning methods in the process of acquiring knowledge, explore English-learning rules, learn and have a good command of the simple way of thinking and scientific learning strategies. Only in this way can students reflect their subject status more effectively, and then take the initiative to study English consciously and scientifically [4].

Next, teaching process is a mutual process between teaching and learning. Students are the subjects of learning and the decision makers of guaranteeing their subject roles. In order to make students bring their subject roles into full play in the teaching activities and put themselves in the roles of the subject, we should try to make the students do the following things.

\section{Know How to Mobilize Their Self-learning Motivation.}

Students' English learning motivation plays an active role in the formation of interest in English learning, which is the basic condition for the formation of students' learning interest. People who own a strong motivation to learn can have a strong learning motivation and actively devote themselves to English learning. 


\section{Know how to mobilize their self-learning initiative.}

Students should set up their learning goals, make study plans, sum up learning methods and establish cognitive structures. They would gain a certain sense of satisfaction in the process of English learning knowledge and solving problems and acquire English knowledge and skills with the active mental state of mind, which would strengthen their basic English knowledge and practice. At the same time, their English knowledge would be conversed into English skills and further developed into the ability of communicating with English, too.

\section{Clear the Purpose of Englis h Learning.}

Now we are in the age of information, and English can be called the supporter of time information. For Chinese people, the fact that they study English equals to open the window of the world, which makes them more closely linked to the world. Only when the students combined the purpose of learning English with their own lives can they be able to make English learning as a part of their own lives, and really enhance their awareness of the subjectivity.

\section{Cultivate Self-innovation Ability}

Self-innovation ability is an indispensable ability of students in the ir learning process. This is especially true for Chinese students when they learn English. Only when they innovate and sum up continuously can they find a suitable learning method. Finding a good method of English learning of their own could double their English learning efficiency [5].

The guiding roles of English teachers are to guide students' to find their own learning methods, help them develop good study habits and cultivate self-learning ability. So English teachers should pay more attention to helping students master the correct learning methods and skills and improve learning efficiency. Therefore, English teachers should concentrate on studying the characteristics and methods of English learning, so that students can learn how to study English and how to study English well. Teachers' teaching methods should be in accordance with the students' learning methods. Study is a gradual learning process, which requires using different methods to lay a solid language foundation in different stages and develop their skills of listening, speaking, reading and writing. In the process of learning, all kinds of sensory coordination activities are helpful for improving memory effect; so the direct teaching method must be used. The teacher should not only review the knowledge that they have learned while teaching new knowledge, so that new knowledge and the learned knowledge could have organic combination, but also guide students to know how to review. Only in this way can the students' subject roles be reflected and their enthusiasm, consciousness and creative of students be played. Thus their learning efficiency could be improved, too.

\section{Conclusions}

In short, English curriculum teaching is a bilateral activity which both the teachers and the students should participate in. The degree of students' participation is very 
important to improve the teaching quality. Teachers should not only adopt a variety of flexible and effective ways to highlight and strengthen the students' subjectivity and cultivate students' subject awareness of English learning, but also make their own teaching truly serve to students' learning.

\section{Acknowledgme nt}

The author wishes to express his sincere thanks to the editor and the anonymous referees for their valuable suggestions and helpful comments which could improve the presentation of the paper.

\section{References}

[1] "English curriculum standards”. Beijing Normal University Press, 2001.

[2] "The theory and practice of the new curriculum reform in English". Li Lisheng. Kunming: Yunnan University Press, 2005

[3] 'On the cultivation of students' English learning initiative by the theory of Constructivism”. Zhao Jinzhu. Education and Occupation, 2007(2)

[4] “Teaching Listening Comprehension". Penny Ur. Cambridge University Press, 1984

[5] "Developmental teaching and the development of students' subjectivity". Pei Dina. Anhui Education Press, 1994 